\title{
供給信頼度解析に基づく送電設備有効利用策の評価
}

$\begin{array}{lllll}\text { 正員 國富 一良 } & \text { 正員 栗原 郁夫 } & \text { (電力中央研究所) } \\ \text { 正員 舘野 澄夫 } & \text { 正員 渡辺 勉 } & \text { (東京黾力) }\end{array}$

\section{Evaluation of More Effective Utilization of Transmission Facilities \\ Based on Reliability Analysis}

Kazuyoshi Kunitomi, Member, Ikuo Kurihara, Member (Central Research Institute of Electric Power Industry) Sumio Tachino, Member, Tsutomu Watanabe, Member (Tokyo Electric Power Co.)

\begin{abstract}
Quantitative evaluation of power system reliability in planning stage is one of the effective approaches to realize more efficient facility investments. Especially, recent movements tow ard more effective utilization of existing facilities calls for precise evaluation of appropriate time of investments, and in this respect, reliability analysis based on a probabilistic method is expected to play an important role as one of the powerful planning tools.

This paper discusses reliability analysis of the specific portion of a trunk transmission network, which supplies bulk power to the metropolitan area. The sequential Monte Carlo method is applied in order to evaluate the effect of yearly demand profile and operation strategies on power system reliability.

Application of the developed tool to a model network revealed that the transfer capability of existing transformers may be increased in probabilistic sense without significant deterioration of reliability, indicating the possibility of investment deferral.

In this paper, effects of applying new short time overload rating on transmission facilities are also examined. Initial short time overload rating on transformers is adopted, which allows more overloads on transformers than conventional rating for relatively short period just after the faults. The reliability analysis showed that this new rating can decrease the opportunities of loss-of-load, and as a consequence, can be effective in improving probabilistic transfer capability of the transformer.
\end{abstract}

キ一ワード : 供給信頼度, 確率論的手法, 基幹系統, 供給能力, 設備而量

\section{1. はじめに}

近年, 電気事業を取り巻く環境は規制緩和の流れの中で, 発電部門への競争の導入, 自己託送制度の導入など大きく 変化してきている。電力流通部門に関しても，一層のコス トダウンに向けて, 既存流通設備のさらなる有効活用と合 理的な拡充を実現することがますます重要になってきてい 更。

現在, 多くの電力会社では電力流通設備の計画に際して 必要な供給能力を確保するために, 想定最大需要のもとで, 単一の設備が停止しても供給支障が極力生じないように設 備の增強を図るという基準 ( $(N-I)$ 基準) を一般的に採用 している。このような確定論的手法は簡明であり, 安全サ イドの評価が得られるというメリットがある。しかし一方 では，事故発生の確率や需要の変動の影響などが充分には 反映されない。実際，年間の最大需要はわずかな時間であ
り，また一日の需要変動でも一般にビークは昼間の時間帯 に限られる。さらに事故の発生確率も送電線の長さや設備 の置かれている環境によって大きく異なっている。このた め, 系統の運用状態を考えれば実際は $(N-1)$ 基準の想定条件 に比べて緩い条件となっている場合が多いと考えられる。 この想定条件と実態の差はいわば「隙間」に相当するもの であり,これを埋めても, 従来の確定論的な信頼度評価の 意味からは，ほとんど影響がないものと考えられる。こう した「隙間」を定量的に見極めた上で流通設備を有効活用 することは，供給能力向上を図る一つの有力な手段となる 引。

このようなさめの細かい供給信頼度の評価を行うには， 従来の確定論的手法に加えて確率論的手法の適用が不可欠 である(1)。わが国でも，確率論的手法に基づく供給信頼度 の定量的評価については，これまでにも二次系統（負荷供 給系統）を対象に解析手法の開発が進められ(2,3)，すでに一 
部で実務への試験的適用も始まっている。一方，基幹系統 に対する供給信頼度の定量的呼価は，一般に電源や種々の 系統運用条件の考虑，さらに事故発生に伴う系統異常現象 が安定度など多岐にわたるため，極めて難しい問題である。 しかし，基幹系統のうち，大規模負荷地域八の供給系統（負 荷供給基幹系統と呼ぶ）については二次系統と同様に放射 状運用が基本であり，また電源の詳細模擬や安定度などの 動的な系統問題を考慮しなくても十分な供給信頼度評価が 可能である。さらに，このように対象系統を限定すること で事故時の復旧模擬など運用実態を踏まえた扱いが容易に 行える。なおこうした部分的な基幹系統への適用に限っ ても上記の「腺間」の有効活用の効果が失われることはな w。

このため，本論文では負荷供給基幹系統を対象に，確率 論的手法に基つく供給信賴度解析とその適用について述心 る。まず，第 2 章では，特に運用条件の影響など，きめ細 かな評価に最も適した手法として時系列モンテカルロ法を 採用した信頼度解析プログラムについて述べるっいで， 第 3 章では具体的適用例として，供給信頼度解析からみた 既存設備の有效利用方策の評価をとりあげ，変電所の供給 能力向上の可能性と, 変圧器の短時間過負荷耐量に対する 柔軟な運用の効果について述ぶる。

\section{2. 負荷供給基幹系統信賴度解析プログラムの概要}

〈2・1>対象系統本論文で対象にする負荷供給基幹系 統は図 1 に示すように大規模負荷地域の周辺に存在する都 心導入変電所から二次系統までを範囲とする。都心埒入変 電所は地域内にとっては電源に相些するものであり，通常 複数䇢所存在し，地域外の基幹系統で互いに連系されてい る。電力は都心導入変電所加基幹送電線によって負荷地 域内に点在する供給変電所に供給され，さらに二次系統で 配電用変電所に送られる。員荷供給基幹系統は基本的には 地中送電線で構成されている。

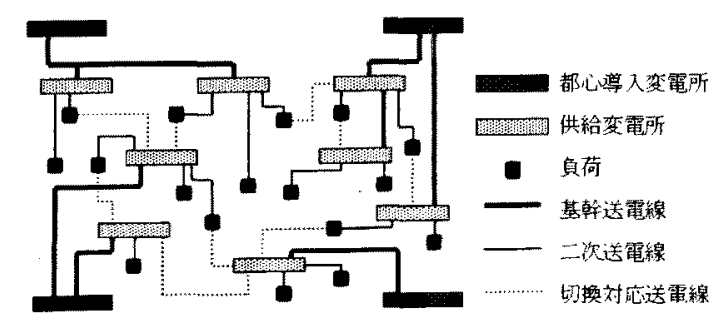

図 1 負荷供給基幹系統の概念図

Fig.1. Trunk transmission network to supply large load center.

供給信頼度解析のためのモデル化に関して，まず電源に ついては都心導入変電所を無限大母線として模擬し、これ については事故発生はないものとした。都心導入変電所か ら供給変電所二次側母線までは本解析の中心であり, 図 2 に示すように回線每に詳細にモデル化するとともにこの 区間で発生する事故定模擬した。供給変電所の二次側母線
より下位の系統については，送電ルート嵲に負荷を縮約し てモデル化した。対象とする系統はず゙て放射状であるが， 各ルートが䘽数回線で構成されるため, 回線間のループ潮 流も考思している。なお，計算される供給信頼度指整は供 給変電所の二次側母線での値である。

事故発生時の停電ないし過負荷の解消は二次系統の負荷 切替えによって行う。責荷切替えのモデル化にあたっては， 実際の基幹系統の設備計画の実態を踏まえ，切替え先の隣 接変電所の変圧器容量が常時容量を超過しないことを前提 に一段切替えのみを模擬した。二次系統の負荷切替えは， 一般に給電指令によるため，ある程度の時間が必要である。 本検討では 1 回線当たり10分とした。

切替え先の変電所に余裕がなく，負荷切替えが行えない などにより過負荷が解消されない場合には，設倩酎量超過 分を「供給支障量」として，信頼度指標（リスク指標）に 計上した。

なお，今回使用した負荷供給基幹系統は需要規模が約 $6 \mathrm{GW}$ で, 都心導入変電所数 5 , 供給変電所数 13 , 二次系 統の縮約した負荷数 78 でる。

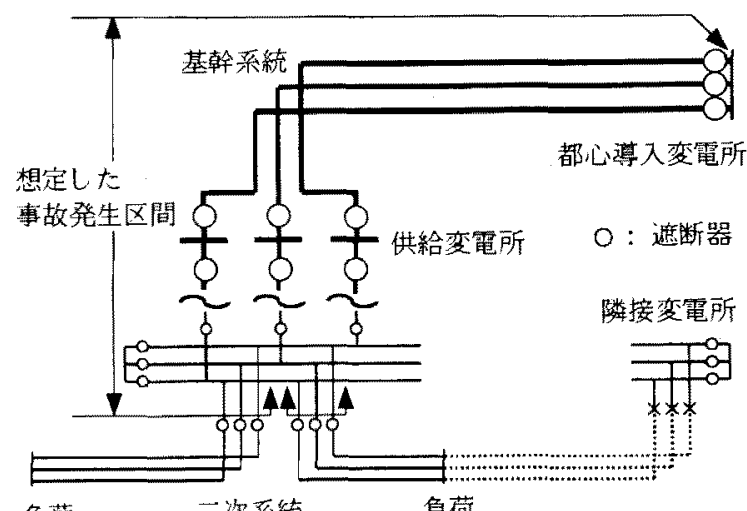

負苚

二收系統

负荷

図 2 負荷供給基幹系統のモデル化

Fig.2. Modeling of trunk transmission network to supply large load center.

〈2・2〉時系列モンテカルロ法に基つく供粭信頼度解析手 法確率論的手法に基づく供給信頼度の解析手法として は，大别して状態列挙法とモンテカルロ法とがあるが。雨 者の違いは系統状態の設定方法にあり，状態列挙法は需要 断面を数パターン想定し，事故設備を「数え上げる」こと により，系統状態を作成するのに対し，モンテカルロ法は 疑似乱数に基づき系統状怠を発生させる。一般に，前者は 電源を含まない送電系統のみの信頼度解析には効率的で， 後者は電源を含む電力系統全体の信賴度解析に特に有効と 言われている(4)。また，モンテカルロ法には，各サンプり ングの間に時間的関缧のない非時系列モンテカルロ法と, 時間を追ってサンブリングを行う時系列モンテカルロ法と がある。

本検討で対象とする負荷供給基幹系統の信頼度解析には 
状態列挙法の適用も考えられるが，前述した通り，今回は 特に需給状沉の変化や設備の運用形態が供給信頼度に与え る影響の評価に重点を置いているため,これらの模擬が容 易に可能な時系列モンテカルロ法を採用した。すなわち， 時系列モンテカルロ法を用いることにより，あたかも実際 の系統を時間を追って運転するように模擬することが可能 となり，実際の事故様相（ある事故による停電規模・復旧 過程）の推移が把握できる。基幹系統では一旦停電を引き 起こすと影響が大きいため，こうした個々の事象の発生条 件とその推移の把握も重要と考える。また, 基幹系統の重 要性からは, 多重事故(ある設備の停止中に別の設備の事 故発生を含む）の模擬も必要と考えられ，こうした事故の 組み合わせの設定が容易な点も，今回，時系列モンテカル 口法を採用した理由の一つである。

概念的な計算の流れは図 3 に示寸通りである。すなわ ち,まず系統状態として需要と設備事故の設定を行う。需 要については 1 時間毎の系統全体の時系列需要を少なくと も 1 年間分準備する。各負荷点への需要の配分は, ピーク 時点の潮流分布をべースに一律に行う。このため, 負荷パ ターンは各負荷点で共通となるが, 業務用需要が中心の都 市部を対象としているため, 地点による差は比較的少ない と考えられる。

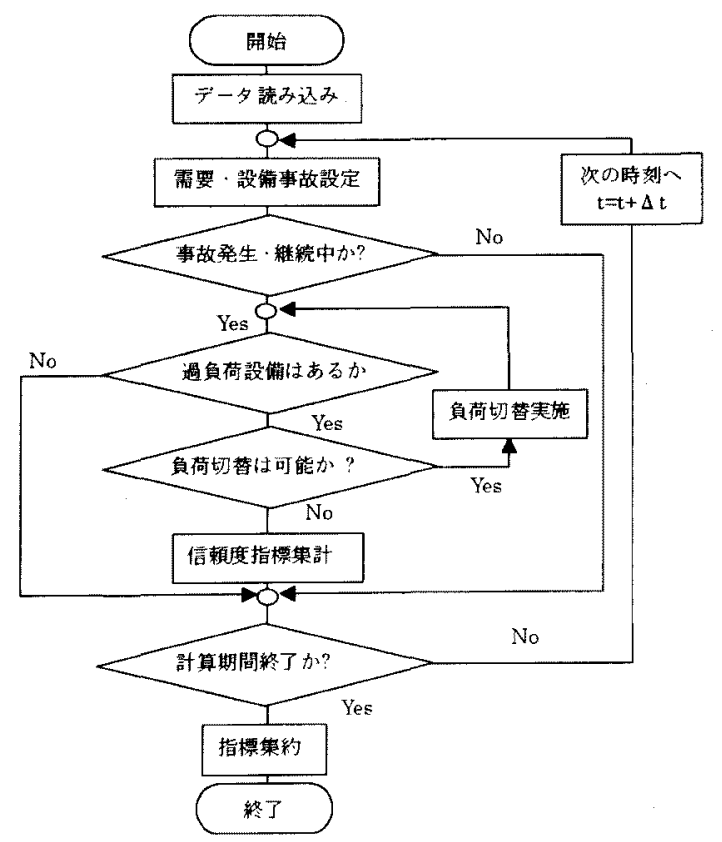

园３時系列モンテカルロ法による信頼度解析フロー Fig.3. Reliability analysis based on sequential Monte Carlo method.

設備状態の設定は 1 時間毎に疑似乱数を用いて, 各設 俑の事故率に応じた確率分布で事故を発生させる。事故の 発生を想定した設備は図 2 に示す範囲内の送電線, 変圧器, 母線, 遮断器である。
潮流計算は対象系統が負荷系統であることから, 直流法 に基づいている。すなわち, 有効電力による過負荷のみを 議論している。過負荷が発生する場合には，く2.1>で述べ たように二次系統の負荷切替えを行い過負荷解消を試みる。 解消できなかった過負荷は供給支障として信頼度指標の算 定に用いる。

以上のプロセスを所定の精度が得られるまで繰り返す。

モンテカルロ法による信頼度指標は, 次式のように各サ ンブル毎の標本の值（供給支障電力量など求めたい指標に 刘応する値)を全サンプル数で割った值として与えられる。

$$
\tilde{E}(F)=\frac{\sum_{i=1}^{N} F\left(x_{i}\right)}{N}
$$

ここに, $\widetilde{E}(F)$ : 求める指標（期待值）， $N$ : サ ンプル数, $F\left(x_{i}\right)$ 標本の值, $x_{j}$ :サンプルされた状態 である。

ただし，本検討では信頼度指標を年間の期待値として算 定するため, サンプリングは 1 時間毎に行うものの，標本 の值は 1 年毎に集計して扱っている。

モンテカルロ法による信頼度解析を行う場合には, サン プル数の制約による計算指標の誤差に留意しなけらばなら ない。一般に, モンテカルロ法による計算誤差は, 指標に 対するその標準偏差の比として次式で評価される(4)。

$$
R U=\frac{\sqrt{V(\widetilde{E}(F))}}{\tilde{E}(F)} \frac{\sqrt{V(F)}}{\sqrt{N} \cdot \widetilde{E}(F)}
$$

ここに, $R U$ :相对䛊差, $V(\tilde{E}(F))$ :指標の分散, $V(F)$ : 標本 $F$ の分散, $N$ :サンプル数である。

表 1 サンブル数と相対誤差（指標：供給支障電力）

Table 1. Sample number vs. relative uncertainty (EPNS).

\begin{tabular}{|c||c|c|c|}
\hline $\begin{array}{c}\text { シミュレーショ } \\
\text { ン期間 }\end{array}$ & 500 年 & 2,000 年 & 10,000 年 \\
\hline 相対䛊差 (RU) & 約 20\% & 約 10\% & 約 5\% \\
\hline
\end{tabular}

注）サンプル数＝シミュレーション期間 $\times 8760$

すなわち，相対誤差は標本の標準偏差に比例し，サンブ ル数の平方根に反比例する。このため, 計算精度を高める には分散を減らすかサンプル数を增やすことが必要である。 分散の低減手法についてはこれまでにもいくつかの手法が 提案されているが(4)，ここでは特に採用していない。サン プル数と相対誤差については，今回の計算条件では概水表 1 の関係が得られている。このため，第 3 章で示す具体的 檢討では，計算時間との兼的台いから，時系列としてのシ ミュレーション期間（サンプル数はシミュレーション期間 $\times 8760$ ) は基本的には 2000 年とした。 
く2-3>供給信頼度指拯 供給支障を評価する尺度とし ては，頻度・量・継続時間などが用いられることが多いた め,ここでは表 2 に示す 4 種類の供給信頼度指標を採用し た。これらはいずれも年間の期待値として与えられる。な お，EPNSについては事故発生直後の供給支障電力の值を 用いている。

表 2 供給信頼度指標

Table 2. Reliability index.

\begin{tabular}{|c|c|c|}
\hline 指標 & 意味 & 単位 \\
\hline \hline LOLD & $\begin{array}{c}\text { 年間の供給支障時間の期待値 } \\
\text { (Loss Of Load Duration) }\end{array}$ & 時間 $/$ 年 \\
\hline LOLF & $\begin{array}{c}\text { 年間の供給支障回数の期待值 } \\
\text { (Loss Of Load Frequency) }\end{array}$ & 回 $/$ 年 \\
\hline EENS & $\begin{array}{c}\text { 年間の供給支障電力量の期待値 } \\
\text { (Expected Energy Not Supplied) }\end{array}$ & $\mathrm{MWh} /$ 年 \\
\hline EPNS & $\begin{array}{c}\text { 年間の供給支障電力の期待值 } \\
\text { (Expected Power Not Supplied) }\end{array}$ & $\mathrm{MW} /$ 年 \\
\hline
\end{tabular}

\section{3. 流通設備有効利用策の供給信頼度からの評価}

ここでは，開発した時系列モンテカルロ法に基うくく供給 信頼度解析プログラムの一つの適用として, 既存流通設備 の有効利用策の供給信賴度から見た評価を行う。

く3・1〉計算条件＼cjkstart対象とした系統はく2.1>で述べた負 荷供給基幹系統である。需要については実績をベースに 1 時間每の年間時系列デー夕を 5 年分準備した。 5 年間の 負荷を用いたのは，各年固有の天候状態などによる恋動を 考虑しつつ, 平均を求めるためである。

表 3 設備事故率(5.6) と修理時間

Table 3. Fault rate and repair time.

\begin{tabular}{|c|c|c|}
\hline $\begin{array}{c}\text { 設備 } \\
\end{array}$ & 事故率 & 修理時間 \\
\hline 変圧器 & 2 2.94/1000台・年 *) & 3 3ケ月 \\
\hline 遮断器 & $0.53 / 1000$ 台・年 * & 1 个月 \\
\hline 地中送電線 & $0.04 / 100 \mathrm{~km} \cdot$ 年 $^{* *}$ & $3 r$ 月 \\
\hline 母線 & $0.90 / 1000$ 本 $\cdot$ 年 $*$ & $1 ケ$ 月 \\
\hline
\end{tabular}

注） ${ }^{*}$ ) 電压階級を無視した平均値

**) 187〜275kV 送電線の平均値

設備の事故率と修理時間については表 3 の通りとした。 修理時間については十分な統計デー夕はないが, 基幹系統 設備に対しては予備品の準備も極めて限定されており，修 理（交換も含めて）が数ヶ月にも及ぶことがある。このた め，今回の検討では代表的な值として，設備に応じて 1 な いし3ケ月を設定した。なお，事故によってはこれほどの 修理時間を必要としないものもあるため, 計算結果は阚し めの值になっていることに留意されたい。
<3-2> 供粭変電所の供粭能力 変電所変圧器の増強計 画においては，以下で定義される(N-1)基準に基づく「有効 稼働率」が指標として使われることがある。有效稼働率は ピーク需要時に変圧器が 1 台停止した場合, 負荷切替えを 考慮した上での残りの健全変圧器の稼働率を表す指標であ る。

$$
T=\frac{\sum_{i\left(i \neq i_{f}\right)} P_{i}}{\sum_{i\left(i \neq i_{f}\right)} C S_{i}+\sum_{j} C W_{j}} \times 100(\%)
$$

ここに, $T$ : 有効稼働率, $P_{i}:$ 健全変圧器の潮流, $C S_{i}$ : 変圧器短時間容量, $C W_{j}$ : 二次系 $j$ 線路の 負荷切替量, $i$ :変圧器番号, $i_{j}$ 停止変圧器番号で ある。

有効稼働率が $100 \%$ を超過すると，ピ一ク時に単一事故 が発生した場合供給支障となる。すなわち, 有効稼働率が 100\%の負荷断面が，(N-1)基準の確定論的手法に基つく変 電所の最大供給能力である。

しかし，実態としてはピーク需要は年間の限られた時間 でしか発生せず，また事故の発生も各変電所で一律ではな いため, 変電所によっては供給信頼度の違いがかなり生じ ていると考えられる。これらは，以前から指摘されてはき たが具体的な評価はあまりなされて来なかった。

図 4 は, 対象系統の代表的変電所の有効稼働率の変化を 需要の增加に対して描いたものである。有効稼働率は, 需 要の増加に伴って線形に増加し，隣接変電所への負荷切替 えができなくなった時点で不連続的に上昇する。

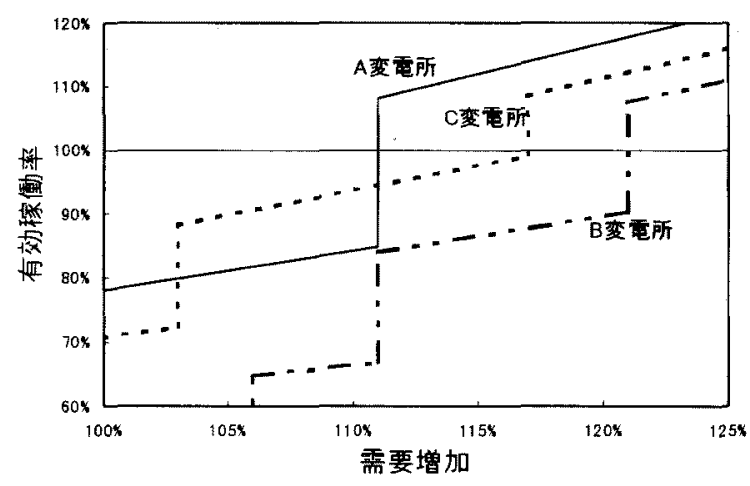

図 4 変電所の有效稼働率

Fig. 4. Effective utilization factor of substation.

図 5 は同じ変電所の EENS（供給支障電力量）の値を計 算したものである。多重事故により，有効稼動率が 100\% 以下でも EENS の值は零にはなっていない。A,C 変電所に ついては需要增加が $110 \%$ を越えた眭点から上昇し始めほ ぼ同様なカーブを描くが, A 変電所は需要增加が $120 \%$ の あたりで急激に増大する。これは $110 \%$ 越えたあたりか ら「隙間」が減少し始め，120\%あたりで「腺間」がほと 
んど無くなることを意味する。後者については，事故によ る設備停止が数か月継続することでその間の高需要時に過 負荷が発生するようになるためである。

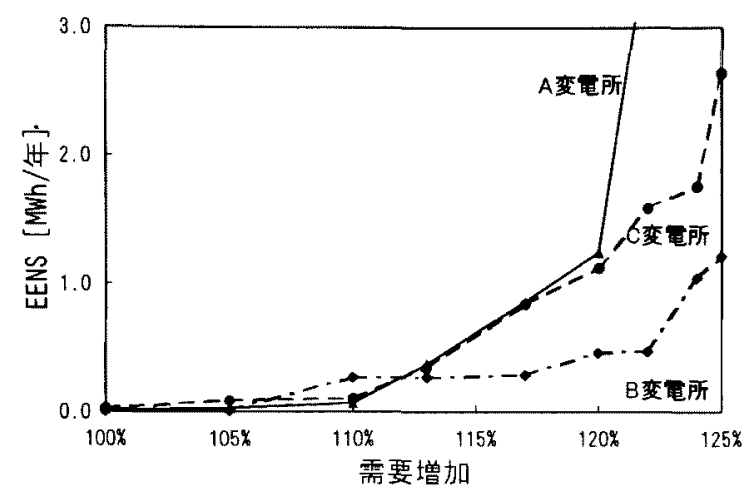

図 5 変電所 0 信頼度指標 (EENS)

Fig. 5. Reliability index of typical substations (EENS).

このように EENS は一般にある需要レベルから急激に悪 化する傾向が認められる。計画基準として EENS の確保す へき信頼度レベルを設定するのには種々の要素を考虑する 必要があるが，少なくとも急激に悪化する点より前の值を 採るべと考える。今，仮に急激に悪化する点をひとつの 目安と考えると，A，C 変電所では有効稼㗢率を用いた従来 の確定論と比べて, 約 10\%ボイント程度のさらなる需要增 加に対して既存設備のままで対応できることになる。すな わち確率論的にみると最大供給能力が, 約 $10 \%$ ポイント程 度向上すると考えられる。

確率論的手法に基づく供給信頼度の定量的解析は，より 実態に即した設備の供給能力の評価を可能とする点で，既 存設備の有効利用をきめ細かに図るためのひとつのッール としての活用が期待される。

〈3・3〉变圧器の設備耐量の細分化の効果従来, 変電 所変圧器の計画を行う場合の設備耐量の考え方は，「常時 容量」と「短時間容量」の 2 本立てで行われている。短時 間容量は，たとえば 2 時間は $120 \%$ 過負荷まで許容すると いうようなものである。ここではこれに対し，さらに短い 時間単位で変圧器の容量を管理することを考え, 細分化し た設備耐量を導入した。

(1) 初期短時間容量の導入効果 変圧器の設備耐量に関 し, 継続時間が短ければ，従来の短時間容量よりも大きな 耐量が存在するという「隙間」に着目すると，事故值後は 從来以上の設備耐量を許容しても, 変圧器自体への影響は 少ない場台があると考えられる。事故直後に，より大きな 設備耐量（初期短時間容量と呼孔゙）を導入すると，网6に 示すように従来の短時間容量の下では供給支障となってい た事故が供給支障とならなくなる。このように，系統の切 替え能力の一層の活用が図られれば，供給信頼度を維持し たままで変電所の供給能力向上が可能となる。なお，本方 式の具体的な奏現は, 過負荷りレ一の段階的整定によって
行うことができる。なお, 送電線については, 変圧器に比 ベて熱的時定数が小さいため，設備耐量の細分化はここで は想定していない。

このような設備耐量の細分化による既存設備の有効利 用策の評価を，従来の確定論に基づく信頼度評価で行うこ とは，検討が煩雑になるなど現実的には困難である。しか し，今回の時系列モンテカルロ法による供給信頼度の定量 的解析によればこうした評価が的確に行える。なお，初 期短時間容量の最大許容時間は本検討では仮に 1 時間と設 定したが，この間に負荷切替えが行かれるため，初期短時 間容量に近い潮流が継続することはない。

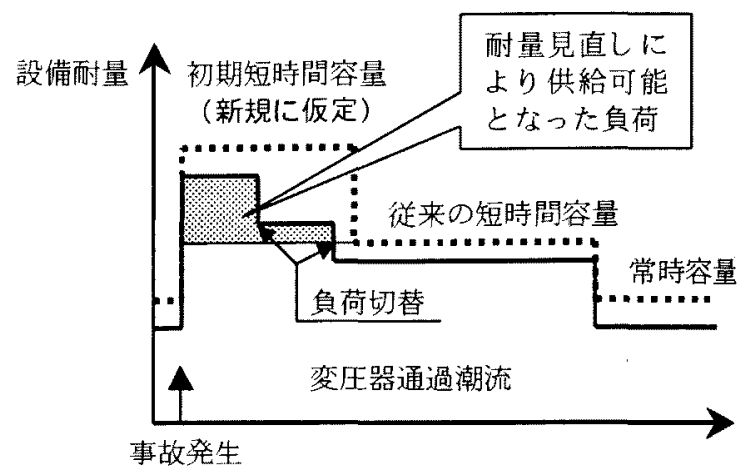

図 6 变圧器の設備耐量の細分化

Fig. 6. Subdivision of overload rating of transformer.

初期短時間容量の影響を全体的に把握するため,まず は対象系統内のすべての変圧器に対して設定されるものと 考えた。供給信頼度指標としては各供給変電所の指標の和 である㥧荷供給基幹系統全体の值を用いる。ただし，EENS ではく3・2>で述べたようにある需要增加断面で，值が急激 に悪化する傾向があり，この断面が各変電所毎に異なるた め, 初期短時間容量導入の全系における効果が不透明にな る可能性がある。このためこうした傾向の少ない EPNS（供 給支障電力）を用いた。

図 7 は初期短時間容量をバラメー夕にとり，需要の增大 に対する全系の EPNS の変化を示したものである。図中で 初期短時間容量 120\%（常時容量に対する割合）は，従来 の 2 段階の容量設定の場合に相当する。

この図から，初期短時間容量の適用によって供給信頼度 が向上しているのがかかる。但し，初期短時間容量が $135 \%$ から 150\%になっても向上効果は少ない。これは，単一事 故で従来の短時間容量を越える過負荷の大きさは小さく, また多重事故の発生も比較的小さいことから，結果的に若 干の容量增加を認めることで，実質的に大きな信頼度向上 効果が期待できることを意味する。計算例では，例えば確 保すべき信頼度レベルを $10 \mathrm{MW} /$ 年とすると，従来の容量 管理では系統全体として 112\%程度の需要增加までの供給 能力であったが，初期短時間容量 $135 \%$ を導入することで 需要增加 $117 \%$ 弱まで,すなわち約 $5 \%$ ポイント程度, 確率 
論的意味での系統全体の供給能力问上が図られることにな る。なお,この図で，初期短時間容量 120\%，露要增加 $117 \%$ の点における全事故中の多重事故の割合は約 $11 \%$ あるる。

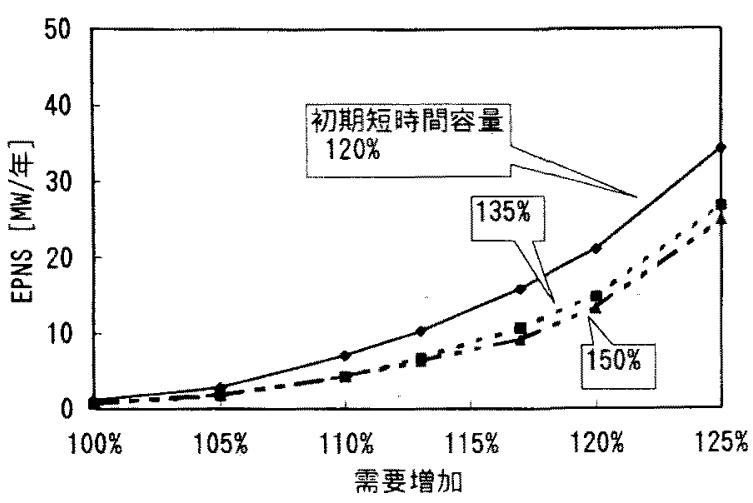

図7初期短時間容量の供給信頼度への影響 (系統指標)

Fig. 7. Effect of initial short time overload rating on reliability index (System index).

つぎに, 初期短時間容量の導入効果を個別の変電所の 変圧器の供給能力の点から見る。図 8 は $<3 \cdot 2>0 \mathrm{~A}$ 変電所 について、初期短時間容量をパラメー夕に EENSを示した ものである。

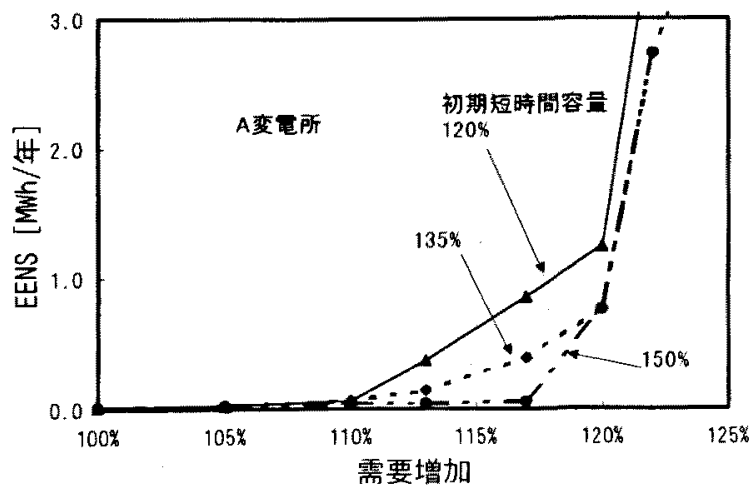

図 8 初期短時間容量の供給信頼度への影響 (A 変電所; EENS)

Fig. 8. Effect of initial short time overload rating on reliability index (Substation "A"; EENS)

EENS が急激に增大する需要より前の値として，仮に $0.5 \mathrm{MWh} /$ 年の信頼度レベルを確保するものとすると, 現状 の短時間容量の考え方では $113 \%$ 程度までの需要増加に対 応できるが, 初期短時間容量 135\%,設定では約 $118 \%$ の需 要増まで対応できることになる。ただし， EENS が急激に 増加する需要断面に近づくと，初期短時間容量の導入によ
る供給能力向上の効果は滅少してくる。なお，この効果も 交電所每に異なるため，実際の適用に当たっては一律でな く，最も効果的な個所を選択すべきである。

（2）年負荷率変化の影響 確率論的意味での供給能力の 向上は「隚間」の活用にあたるため，需給条件などの変化 によって影響を受ける。ここではその一つの例として年負 荷率の向上の影響について調べる。

ここで想定した負荷率の変化パターンは，蓄熱設備の普 及等により，冷房負荷の平準化が図られ，夏季の7月から 9月にかけてピークカット，ボトムアップが達成されたと いうものである。年負荷率は，変化前の基隼ケースが5 年 平均て $56.1 \%$ ，変化後が $59.2 \%$ で約 $3 \%$ の負荷率向上を見 込んだケースである。

想定した負荷率変化バターンはピークカットを含むた めピーク時の負荷レベルが低下する。しかし，今回の検討 では，評価の考え方としてピーク負荷レベルを一致させた 場合を考える。すなわち，負荷平準化策が効果を発揮する とともに一方では需要の增加もあり，結果的にピークは変 わらず負荷形状のみが変化した場合について考える。

図9は解析結果である。従来の確定論的評価では年負 荷率が変化してもピークが変わらなけれは敌頼度は基本的 に不変となるが，実際は停頼度レバルが若干低下する。こ れは，高需要の時間帯が増え，事故時に過負荷が発生する 確率が高まるためである。また，特に需要增加が大きい場 合には信頼度の低下の度合いは大きくなる。

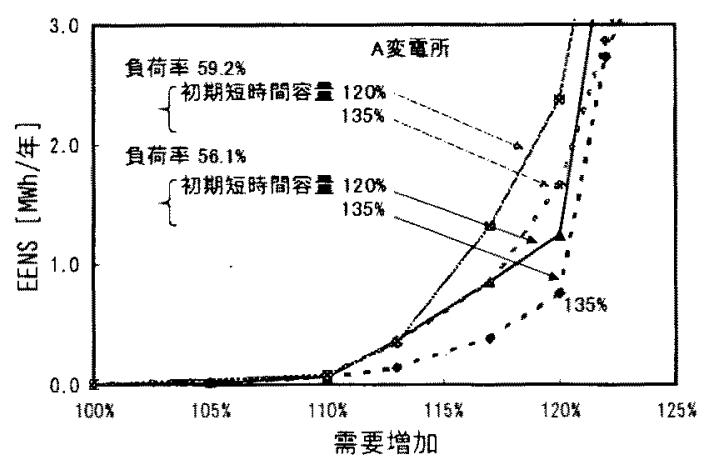

図 9 負荷率问上の供給信頼度への影響 Fig.9. Effect of improvement of load factor on reliability index.

変圧器に対する初期短時間容量の設定による確率論的 意味での供給能力向上効果は，負荷率が低い方が若干大き い。これ姑，ピークを不变とする負荷率の问上は，有効活 用できる系統状態の「腺間」の相対的減少に相当するため でる。

4.むすひ

電力流通部門に対しても設備投資の一層の效率化が求め 
られる中で, 確率論的手法に基づき供給信頼度を定量的に 評価し, 送変電設備計画に反映させることは一つの有効な 手段と考える。確定論的手法に基づく $(N-1)$ 基準は今後も基 本となる信頼度基準であろうが, 代替案のより細かな評価 や運用等の見直しによる影響の評価など, 確定論的手法で は評価が困難な場合に確率論的手法を合わせて活用してい くことが重要と考える。

このため，本論文では基幹系統のうち，大規模需要地八 の供給系統を対象に時系列モンテカルロ法による供給信頼 度解析プログラムの開発を行った。時系列モンテカルロ法 は幾つかある信頼度解析手法の中で, 最も実態に近い信頼 度解析が比較的容易に実現可能な手法である。

開発した手法を, 変電所の供給能力向上の評価と, 変圧 器の設備耐量の運用を細分化した場合の評価に適用した。 その結果, 変電所供給能力については, 信頼度レベルを実 質的には悪化させることなく向上できるケースがあること が明らかになった。また, 変圧器の設備耐量に関して, 新 たに初期短時間容量を設定することで供給信頼度の向上と 供給能力の向上が図られることが示された。

既存設備の有効利用は, 電力流通部門の効率化にとって 一つの重要な要素であり，これを供給信頼度への影響を定 量的に見極めながら進めていくことは重要である。今回開 発した負荷供給基幹系統の供給信頼度評価システムはその ための一つの有効な手段と考える。

今後の課題として, 適用面では種々の既存設備有効利用 策の評価の実施, 手法面ではモンテカルロ法の効率化, 需 要特性の扱い, さらには外輪系統や電源を含めた基幹系統 全体の供給信頼度評価手法の開発が重要である。これらに ついては現在開発を進めている。なおここらとは別個に， 初期短時間容量の設定など既存設備の有効利用策が機器固 有の信頼度に及ほす影響について検討することも重要であ る。

(平成 10 年 5 月 8 日受付, 同 10 年 9 月 29 日再受付)

\section{文 献}

(1) "Power system reliability analysis. Application guide" CIGRE WG03 of SC38 (Power system analysis and techniques) - 1987

（2）内藤, 杉山, 諸住: 「電力負荷送電系統の供給信頼度評価 システムの開発」学会論 B,110,929〜937 (平 5.10)

(3) 栗原, 松本, 田中: 「二次系統の供給信頼度解析システム の開発」学会論 B,117, 585～593 (平 9.4)
(4) “Development of a Composite System Reliability Evaluation Program. Volume 1: Methodology and Project Results", EPRI EL-6926, V1 1990

(5) 電気共同研究 第 41 巻 第 5 号「変電設備信頼度向上対 策」(昭 61.2)

(6) 「平成 6 年度 電気事故統計」資源エネルギ一庁公益事 業部技術課編（平 8.3）

國富一良（正員）1960 年 5 月 6 日生。1986 年 3 月東

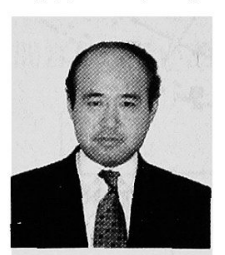
京工業大学大学院理工学研究科電 気・電子工学専攻修士課程修了。同 年東京電力（株）入社。平成 8 年 7 月より (財) 電力中央研究所電力シ ステム部に勤務。主として電カシス テムの計画に関する業務・研究に従 事。

栗原 郁夫（正員）1953 年 6 月 5 日生。1982 年 3 月東

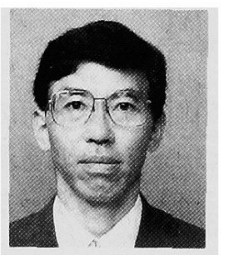
京大学大学院電気工学専門課程博士 課程修了。同年 (財) 電力中央研究 所入所。1986〜1987 年アメリカ合衆 国テキサス大学アーリントン校客員 研究員。主として電力システムの計 画・運用技術に関する研究に従事。 工学博士。1992, 98 年電気学会論文 賞受賞。IEEE Senior Member。

舘野澄夫（正員）1964 年 7 月 30 日生。1990 年 3 月京

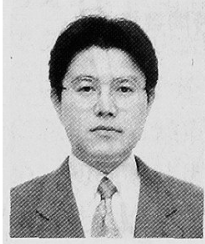
都大学大学院工学研究科電気工学第 二専攻修士課程修了。同年東京電力 （株）入社。現在，同社技術部勤務。 主として基幹系統の計画に関する業 務に従事。

渡辺勉 (正員) 1953 年 4 月 29 日生。1978 年 3 月京

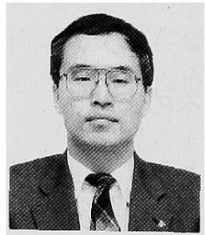
都大学大学院工学研究科電気工学専 攻修士修了。同年東京電力（秼）入 社。現在, 同社技術部勤務。主とし て基幹系統計画（UHV，50 万Vケ一 ブルなどの新技術関連の系統計画） に関する業務に従事。 